I I UC STUDI ES

ISSN 1813-7733

Vol. - 3, December 2006 (p 45-54)

\title{
The Use of Geometric Conceits in Exposition of Love in Metaphysical Poetry
}

\author{
Md. Eftekhar Uddin
}

\begin{abstract}
The language, used by Metaphysical poets is highly evocative and infused with multi-dimensional meaning. It demands comprehension and sensitivity on the part of the reader to grasp out the inner aspect of a poem. Love, being a universal feeling gets expression through the hands of different poets in different ways. The exposition of love in Metaphysical poems has shaped up in a unique way because of the juxtaposition of geometry in it. Straight line and circular line are the two components of geometry. Straight line being regarded as imperfect one as it has no limit and end is used as a vehicle to convey the imperfection of love in Metaphysical poems. On the other hand, circular line, being treated as a perfect one is used to express a harmonious union of love between human beings and also between God and human being. The article aims at exploring such conflation of love with geometry in the poetic works of John Donne, Henry Vaughn, Andrew Marvell and George Herbert, the four major Metaphysical Poets.
\end{abstract}

Since the origins of time, luminaries of the philosophical, theological and literary worlds have been inspired by two of the most elementary geometric figures, the circle and the straight line, to formulate and express original abstractions on arguably life's most prevalent and powerful emotion, love. Through the poetic verse of John Donne's 'A Valediction: Forbidding Mourning'1 and Henry Vaughan's 'The World' an examination of circular conceits will demonstrate the nature and perceptions of love in the context of the Renaissance. Juxtaposed with these texts, 'The Definition of Love'3 by Andrew Marvell and 'The Search' ${ }^{4}$ by George Herbert will indicate, via the use of lineal conceits, opposing sentiments on the characteristics of love, being a strong and passionate predilection of affection for another.

Whilst purists may argue that a consistent, literal and specific definition of Metaphysical Poetry is non-existent, numerous varying suppositions have been compiled over time to produce a progressive interpretation of this seventeenth century style of verse. While all contemporary theories on the nature of Metaphysical Poetry rest on the essayists' perceived understanding and commentary of distinct texts, a firm consensus is often found amongst literary critics in relation to the vital attributes of Metaphysical Poetry.

Throughout the seventeenth century English Renaissance, spanning the years from 1570 through 1660, the Metaphysical Poets were often, and still are, distinguished by the complex level of ingenuity, intellectuality and obscurity found in their work. Metaphysical texts, primarily characterized through the conflation of traditional form with seditious linguistic techniques such as satire, irony, wit, parody and rhetoric, generate a microcosmic emphasis in many of the texts. Within the original Metaphysical context, highly innovative and revolutionary attitudes pertaining to life,

* Lecturer, Dept. of English Language and Literature, International Islamic University Chittagong. 


\section{IIUC Studies, Vol. 3}

including aspects of faith, human frailty and introspection were portrayed through lyric verse, to create an emotional and devotional tone. Introspection, being 'a careful examination of one's own thoughts, impressions and feelings ${ }^{5}$ allowed the poet to create a certain atmosphere in a text that acknowledges the acceptance of orderly systems of thought and feeling, resulting in a direct and often austere manner of speech. A strong emphasis on the contemplation of death, and a considerable interest in the soul, both in a religious and philosophical domain, allowed the Metaphysical Poets the use of the individual voice, especially evident in Donne's devotional sonnets. It is, however, the depiction of love that unites all Metaphysical Poets of the seventeenth century.

Helen Gardner captures the essence of the Metaphysical Poets' vision when she describes love as explicitly being 'the great Metaphysical question of the relation between the spirit and the senses' This is the prominent emotion that will be displayed, through the use of the geometric conceit, in this paper.

The extensive technical use of the conceit in seventeenth century verse immediately places any Metaphysical text in its historical context amidst the development of canonical English literature. The conceit's subtle use of controlled connotation to enrich the meaning of poems, with the associated dependence on the imaginative sensitivity of the reader, and its consistent evocation of paradox, instills in the text numerous levels of meaning. The conceit, advocating an origin which is specifically intellectual rather than sensuous, juxtaposes a number of dissimilar images to establish a marked discord in mood, resulting in the device functioning as a vehicle to allow numerous interpretations or readings.

Often when a conceit is to be defined, Helen Gardner's authoritative definition is commonly referred to:

"A conceit is a comparison whose ingenuity is more striking than its justness, or, at least is more immediately striking....It is used...to persuade, or it is used to define, or to prove a point...The poem has something to say which the explicates or something to urge which the conceit helps forward."

In recognizing the conceit as being an intricate and extended metaphor used frequently in Metaphysical Poetry, a geometric conceit is based on this notion. However, this subset order of conceit is specific to the use of elements from the scientific and mathematical worlds to express particular emotional and passionate conditions of life. Notably, Collins English Dictionary defines geometry, and hence geometric, as being 'the branch of mathematics immediately associated with points, lines, curves, surfaces and shapes.' (p.229).

For centuries lineal geometric figures, being straight, and especially parallel lines have been considered inferior and imperfect objects, particularly in comparison to circular or spherical figures. Both have numerous symbolic connotations in all expressions of mathematics and literature that allow advanced and detailed examinations of their use in diverse contexts. The motif of the circle, used extensively in John Donne's poetry, is particularly revealing when analyzing the nature and characteristics of love in one of his most famous texts, 'A Valediction: Forbidding Mourning'. 


\section{The Use of Geometric Conceits in Exposition of Love in Metaphysical Poetry}

Presumed to be composed around the year 1611 as a parting dedication for his wife, Donne's 'A Valediction: Forbidding Mourning' is arguably his most passionate and emotive piece and certainly his most renowned. This poem urges that physical separation cannot affect a love which is spiritual, perfect and endless, and therefore Donne's language turns a painful farewell into a magnificent affirmation of love.

Quintessentially, the geometric conceits employed by Donne in 'A Valediction: Forbidding Mourning' can be classified into three principal groups which make them individually different from one another. However, in the same extent to which each conceit in this text is different, all three have common fundamental principles and attributes which immediately characterizes them as being conceits. In Donne's attempt to depict the perfect and complete nature of his love, the recurring motif of the circle is used in different forms.

The first of these circular geometric conceits displaying love in Donne's ' $A$ Valediction: Forbidding Mourning' can be found in stanzas three and four.

"Moving of th' earth brings harms and fears ;

Men reckon what it did, and meant ;

But trepidation of the spheres,

Though greater far, is innocent.

Dull sublunary lovers' love

-Whose soul is sense-cannot admit

Of absence, 'cause it doth remove

The thing which elemented it."

(Line-9-16)

Donne's extensive use of astrological allusions, particularly in reference to the expansive universe, is evident in these two stanzas as a means of representing a macrocosmic understanding of the condition of human love. Further, in referring to 'the spheres' and 'sublunary lovers,' both functioning as circular conceits in a metaphorical sense, Donne proposes his love as being spiritual and perfect; starkly contrasted with the simple and physical 'things which elemented' others.

The production of literature does not exist in isolation, but rather is shaped by social and cultural change. In a period where many traditions were being challenged and scientific and theocratic functions were being vanquished, significantly new patterns of feeling and thought emerged. ${ }^{7}$ This is especially true in regard to the astrological discoveries concerning the Ptolemaic system. In the years just prior to Donne's composition of 'A Valediction: Forbidding mourning', this revolutionary idea changed societal perceptions of the Earth and its newfound significance in the universe. Therefore, Donne's poem in its form, structure, content and meaning, reflects the changes apparent in his society, while continually promoting the perfection of personal love on a general scale.

In continuing the astrological conceit through to the fourth stanza, 'sublunary,' meaning below the moon, is the area in which all physical life exists and is subject to change. It was thought that all life and love which existed below the moon was of an imperfect nature as it only existed in the lineal path between the earth and the moon. Therefore, Donne's assertion of difference on the first line of stanza five, 'but we by a love so much refined,' demonstrates the encircling patterns of love that may only occur in the outer universe, above the moon. 


\section{IIUC Studies, Vol. 3}

The motif of the circle, consistently evoking simple images of perfection through the use of the geometric conceit and the cycling rhyme pattern of the poem, continues into the sixth stanza, albeit in a more abstract fashion.

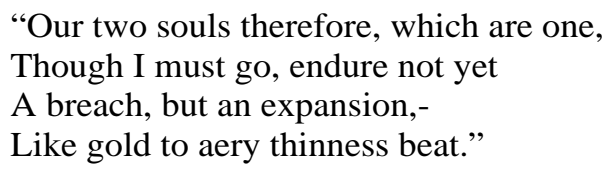

(Line-21-24)

Here, Donne uses the conceit of alchemy, being the ancient art of chemically altering basic elements into precious metals, in order to display his fervent and spiritual love for his wife. This conceit aids in explaining the strength of the couple's love when one must leave the other. When Donne writes 'Like gold to aery thinness beat,' he induces thoughts of a love that is being stretched to span time and distance, and a love that is too strong to be breached or broken. In utilizing a conceit which employs the most precious and perfect metal as its focus, Donne is using the figure of a circle to convey such perfection in human love. Approximately developed in 2600 B.C, the alchemical symbol for gold is a circle with one point located in the exact center to demonstrate the complete solidarity and taintless nature of the new element formed. ${ }^{8}$ This perfection, also reflected in the Aristotelian theories of geometry, is continually manifested in 'A Valediction: Forbidding Mourning' and is evident as Donne's pivotal motivation and poetic strategy for composing this powerful representation of sublime love.

Arguably however, it is Donne's final conceit employed in 'A Valediction: Forbidding Mourning' which emphasizes the specific functions of the geometric conceit as being a primary poetic technique used to allude to spherical connotations of the physical world, to capture the essence of the Metaphysical.

Donne's famous 'compass conceit' initially appears in the seventh stanza of 'A Valediction: Forbidding Mourning' and explicitly demonstrates the ways in which a circle is representative of pure and spiritual love. Idealizing the circle being the geometrical figure of eternal perfection in the Renaissance context, where its perfection is evident as its center is equidistant from every point on its circumference, this circular conceit entertains the notion that the personified compass is indicative of, the separation that the two lovers' souls will endure over the course of time. 'If they be two, they are two so/ As stiff compasses are two' (line.25-26). The compass, commonly used only as a mathematical instrument to construct perfect circles, depicts the foreshadowing of the perfect union of the couple's souls when the fixed foot 'makes thy circle just/ And makes me end where I (began)' (line.35-36) The tone of Donne's text moves towards a sense of completion and finality, in a cyclic structure, primarily through the use of the geometric, circular conceit. The numerous connotations provoked by this basic mathematical figure, are employed successfully and evocatively by Donne, in order to illustrate the perfection of human love in its original seventeenth century context.

Composed some decades after Donne's completion of 'A Valediction: Forbidding Mourning', Henry Vaughan's metaphysical poem, 'The World', may be regarded as simply an aspiring shadow of Donne's eminent poem. Vaughan's poem, similar in nature and liberal contextual values, uses the geometric conceit of the circle, as a profound and complex symbol, to illustrate the perfect love between a human being and the divine God. 


\section{The Use of Geometric Conceits in Exposition of Love in Metaphysical Poetry}

Unlike 'A Valediction: Forbidding Mourning' where the poet focuses primarily on the mortal affection between two human figures, 'The World' seeks to demonstrate the eternal love attainable between an ephemeral and an omnipotent being. Furthermore, this poem explores the notion that God's perfect and heavenly love for the individual far exceeds any mortal love attainable on Earth. In doing so, Vaughan successfully uses the conceit of the ring throughout the poem to enhance his discussion.

In the first stanza of 'The World', Vaughan introduces the geometric conceit of the ring to exemplify the perfection of eternity and immediately juxtaposes this with the adversities of the physical world.

"I saw the eternity the other night,

Like a great ring of pure and endless light

All calm, as it was bright;

And round beneath it, Time in hours, days, years

Drive'n by the spheres

Like a vast shadow mov'd; in which the world

And all her train were hurl'd.

(Line-1-7)

The vision which the poet witnessed as 'a great ring of pure and endless light' (1.2) and labeled as 'Eternity,' can be interpreted as an illusion of the divinity of God in heaven. The poet emphasizes a sense of eternity that is described as radiant and joyful, yet the persona never ceases to ignore the complexities of his ordinary life. In doing so, the audience is shaped to recognize that in an imperfect world described as 'doting' and 'darksome,' perfect human love is impossible, and therefore insinuates that perfect love may only be achieved in a realm separated from the physical Earth.

In the first two stanzas of 'The World', Vaughan's symbol of the ring is representative of all manifestations of God, heaven and a pure, unconditional love for an Earthly being. The geometric, circular conceit of the ring is employed to successfully convey the sense of entire and complete love, only available through God. As the poem progresses into the third and fourth stanza, Vaughan promulgates a second geometric conceit, whereby the circle or ring continues to promote the perfection of certain forms of love.

"This ring the Bridegroom did for none provide, But for his bride."

(Line-59-60)

These final lines of Vaughan's poem convey an epigrammatic tone. A responder's first impression upon reading the second last line of the text may be to believe that the poem's focus has changed from a divine love to that of a love expressed between a bride and groom. However, 'Vaughan's royalist, High-Church position'9 would indicate that the persona's bride is in fact Christ, and that the ring is not a wedding band, but a metaphor for the persona's perfect and sinless soul being offered to God. At the original time of publication in the 1655 Silex Scintillans, Vaughan inscribed the verse from 1 John 2: 17-18 at the conclusion of his poem, 'The World'.

"His Disciples remembered that that the scriptures said, "My devotion to your house, O God burns in me like a fire."10 


\section{IIUC Studies, Vol. 3}

Upon reading this clause from the Bible, a responder may understand why Vaughan chose a circular conceit to depict the perfect love available between his persona and his God. The circle, being a plane figure which rotates on an axis to produce a circular orbit, demonstrates a perpetual and comprehensive emotion, reciprocated by the physical being and the spiritual God equally.

In opposition to 'A Valediction: Forbidding Mourning' by John Donne and 'The World' by Henry Vaughan, 'The Definition of Love' by Andrew Marvell, demonstrates 'how the course of true love never did run smooth', ${ }^{11}$ through the use of lineal, geometric conceits.

Composed in 1652, 'The Definition of Love' by Andrew Marvell features a structured argument that conflates intellect and passion in an attempt to define the nature of his own personal love. The poetry of Marvell, marked by 'extraordinary variety and range,'12 consistently makes extensive use of the Metaphysical element of the conceit, and makes transitory allusion to the already discussed compass conceit in 'A Valediction: Forbidding Mourning', to pronounce his thoughts on the characteristics of love.

Marvell's allusion to the geometric conceit of the compass invented by Donne begins in the third stanza of the poem. This allusion was greatly influenced by, and then further developed, as the literary context in which Marvell composed his poem progressed, and therefore Donne's established impression of style and technique became evident throughout Marvell's later work.

"And yet I quickly might arrive

Where my extended soul is fixed

But fate does iron wedges drive

And always crowds itself betwixt.”

(Line 9-12)

In Donne's 'A Valediction: Forbidding Mourning', the poet uses this circular conceit to demonstrate the perfect and complete nature of love between two individual people. In 'The Definition of Love', Marvell utilizes this conceit only as a vehicle to illustrate the difference between the perfect, unattainable love and the obscurities found in personal relationships. To successfully convey this strong sense of the remote in personal love, Marvell adopts the technique of the lineal conceit. Throughout the poem, there are three separate instances in stanzas six, seven and eight where Marvell uses the image of a line to convey his emotions.

The initial introductory stanza of 'The Definition of Love' establishes a belligerent tone where Marvell expresses the couple's love as being 'strange and high' and 'begotten by despair upon impossibility.' This comprehension and understanding of an afflicted love is embodied throughout the poem, and thus, the responder gains the impression that the persona desires a stronger love consuming elements of the body and soul. This excerpt from Andrew Marvell's poignant poem demonstrates, through the use of the planisphere functioning as a lineal conceit, the tainted elements of human love.

"Unless the giddy heaven fall,

And the Earthsome new convulsions tear;

And, us to join, the world should all

Be cramped into a planisphere.”

(Line-21-24) 


\section{The Use of Geometric Conceits in Exposition of Love in Metaphysical Poetry}

A planisphere being 'a flat two-dimensional projection of the world, ${ }^{, 13}$ is designed by ruling a series of collinear parallel lines to accurately graph the topography of the Earth. The planisphere instinctively conveys certain images to the responder of the lovers being distanced, perhaps physically, but more predominantly spiritually. The lines ruled on the planisphere separate the lovers 'as the distant Poles have placed' them, and may only be reunited in both a physical and spiritual domain if 'the giddy heaven fall.' Therefore, in this regard, the lineal geometric conceit displays the imperfection of human love.

Marvell's generally abstract ideas pertaining to the imperfection of human love are definitely stated in the seventh stanza of the poem through the conceit of the parallel lines.

$$
\begin{aligned}
& \text { “As lines (so loves) oblique may well } \\
& \text { Themselves in every angle greet; } \\
& \text { But ours so truly parallel, } \\
& \text { Though infinite, can never meet.” }
\end{aligned}
$$

(Line 25-28)

In this seventh stanza, Marvell compares his love to 'oblique' or indirect running lines to convey a sense of deceit in their love, therefore making it imperfect. Throughout this lineal conceit however, Marvell summons the notion of infinity, usually an aspect associated with the image of a circle, in an endeavor to convince himself, and perhaps his audience, that his love is of a perfect nature. Observed in the final line of this stanza, an apparent and sudden sense of resignation is evident as the narrator concedes that their love 'can never meet' as it is so 'truly parallel'. Hence, Marvell's use of the lineal conceit verifies to his persona, the partner and his responding audience that loves in all circumstances is impossible. The clinical rather than emotive title of Marvell's poem, 'The definition of Love', and the shades of specialized mathematical or geometric usage contributes firmly to this interpretation.

The last of the geometric conceits practiced by Marvell is found in the eighth and final stanza of the poem. Marvell's strong use of astrological allusions throughout the text culminates in the closing verses of the poem, by using the lines and patterns of the stars to describe fate's opposition of their love.

"Is the conjunction of the mind,

And opposition of the stars.”

(Line-31-32)

Through the use of this astrological conceit, the narrator is confidently arguing that the alignment of the stars is in direct opposition to the love that the couple wishes to share. In Marvell's, British Renaissance context, a considerable emphasis was placed on astrology when concluding the outcome of certain decisions, as the stars and planets were often considered to be representations of Greek or Roman gods. In this regard, the line of the stars and therefore the gods predetermined the imperfection of the couple's love which is subsequently mirrored in the line or opposition of the stars.

In a similar way to Andrew Marvell, George Herbert employs various lineal geometric conceits to successfully convey the notion of incomplete and imperfect love in the seventeenth century Renaissance period. George Herbert's poem 'The Search' differs from Marvell's poem in the same what that 'A Valediction: 


\section{IIUC Studies, Vol. 3}

Forbidding Mourning' by Donne, differs from 'The World' by Henry Vaughan. As previously noted, 'The Definition of Love' composed by Andrew Marvell, discusses the imperfection of love between two human beings through the use of three lineal conceits. However 'The Search', by adopting a similar use of the geometric lineal conceit, displays the imperfect nature of love between a mortal persona and a distanced God.

The opening three stanzas of George Herbert's poem 'The Search', depicts the persona questioning the love and power instilled in God, and further seeks to search for these qualities perceived to be embodied in a physical being. The reservations and doubts which the persona holds towards his God are blatantly exposed when the persona states 'O whither art Thou fled, My Lord, my Love,' (l.1) immediately indicating the absence of pure and perfect love. This notion of imperfection is strengthened further in the following stanzas through the use of the lineal geometric conceits, which are then rigidly juxtaposed with the circular conceits employed by Herbert, in order to demonstrate a sense of comparison. Throughout the first few stanzas, a strong sense of selfishness and ignorance on the persona's part is portrayed, as he is unable to understand that God is a spiritual being rather than a physical.

In the same way that Marvell employs the circular conceit of Donne's compass, Herbert adopts 'Thy Ring' to exemplify and comment on the perfect nature of love. A circle or ring, being the ultimate symbol for commitment and completeness is evident in stanza nine and allows a powerful contrast in stanza eleven to follow.

$$
\begin{aligned}
& \text { O let not that of anything, } \\
& \text { Let rather brass, } \\
& \text { Or steel, or mountains be Thy ring, } \\
& \text { And I will pass. }
\end{aligned}
$$

Stanza eleven demonstrates the first use of a lineal geometric conceit to convey notions of imperfection. The lineal conceit utilized in this stanza has paradoxical undertones which, to a certain extent, conceptualizes an inversion of the natural order. By describing East and West touching, the poles kissing and parallels meeting, Herbert is physically illustrating a bizarre location where God apparently is, and by doing so, emphasizes the spiritual distance from the persona.

Thy will such a distance is,

As that to it

East and West touch, the poles to kiss,

And parallels meet.

(Line- 41-44)

Throughout stanza thirteen, Herbert employs the second lineal conceit in his poem, 'The Search'. Towards completion of the poem, the persona in the text comes to realize the imperfections of his relationship with his God, and therefore asks to be restored and to take the bars and lengths away. By definition, a bar can be 'a long piece of rigid material, used especially as an obstruction, confinement, fastening or weapon.' The use of these bars and lengths as lineal conceits in Herbert's work, demonstrates how the straight line can hinder and obstruct love in even spiritual relationships, making this conceit particularly successful. 


\section{The Use of Geometric Conceits in Exposition of Love in Metaphysical Poetry}

O take these bars, these lengths, away;

Turn, restore me:

'Be not Almighty,' let me say,

'Against, but for me.'

(Line- 49-52)

George Herbert's poem, 'The Search', demonstrates, through differing lineal geometric conceits, and the subsequent use of specific circular conceits, the imperfect nature of love between a human persona and the divine God. This imperfection of love, whilst ordinarily seen in secular human interactions, may also be observed in religious relationships, especially in a seventeenth century, British Renaissance context.

As is evident in John Donne's 'A Valediction: Forbidding Mourning' and 'The World' by Henry Vaughan, the geometric figure of the circle, adapted into the literary form of a conceit, is successful in demonstrating the perfection of love in a British, seventeenth century context. Adapted from Aristotelian times and developed through to the early Renaissance period, this symbol of perfection conveys a sense of unity and eternity in many varying forms of love affinities. Further, the use of the geometric conceit in exemplifying this perfection is utilized not only in mortal human love, but may also be adapted to encompass spiritual and religious relationships accordingly. In contrast, Andrew Marvell's 'The Definition of Love' and George Herbert's 'The Search', offer the lineal geometric conceit so as to demonstrate the imperfect qualities of love in both human and spiritual relationships. These imperfections commonly attributed to a lack of knowledge and understanding of what primarily constitutes the emotion of love, is frequently demonstrated through the emergence of a circular, and thus perfect geometric conceit.

\section{References}

1. Donne, John (1896), Poems of John Donne. Vol I. E. K. Chambers, ed London, Lawrence \& Bullen, P. 51-52.

2. Vaughan, Henry (1896), The Poems of Henry Vaughan, Silurist. vol I. E. K. Chambers, Ed. London, Lawrence \& Bullen Ltd., P.150-152.

3. Marvell, Andrew) 1892), The Poems of Andrew Marvell. G. A. Aitken, Ed. London: Lawrence \& Bullen, P. 73-74.

4. Herbert, George (1886), The Poems of George Herbert. Ernest Rhys, Ed. London: Walter Scott, 167-169.

5. Hornby, A S., Oxford Advanced Learner's Dictionary of current English. Sixth Edition, Oxford. Oxford University Press. P.683

6. Gardner, Helen (1957), ed. The Metaphysical Poets. London: Penguin,P.17

7. "Reformation and Restoration". Encyclopedia Britannica. $<$ "http://www.britannia.com/history/h70.html>

8. "Gold: Historical Information." WebElements. $<\underline{\text { http://www.webelements.com/webelements/elements/text/Au/hist.html }>~}$ 
IIUC Studies, Vol. 3

9. Van Emden, Joan (1986), The Metaphysical Poets. Hampshire: Macmillan,P.71

10. Whealon, John Francis (1988), ed. The Good News Bible. Nashville: Catholic Bible Press, John2:17-18

11. Shakespeare, William (1984), A Midsummer Night's Dream,Cambridge: Cambridge University Press, I. i.

12. Eliot, T.S. (1953), "The Metaphysical Poets." Selected Prose. Harmondsworth: Penguin,P.56

13. Blunden, Edmund (1969), On the poems of Henry Vaughan. New York: Russell and Russell, P.36 